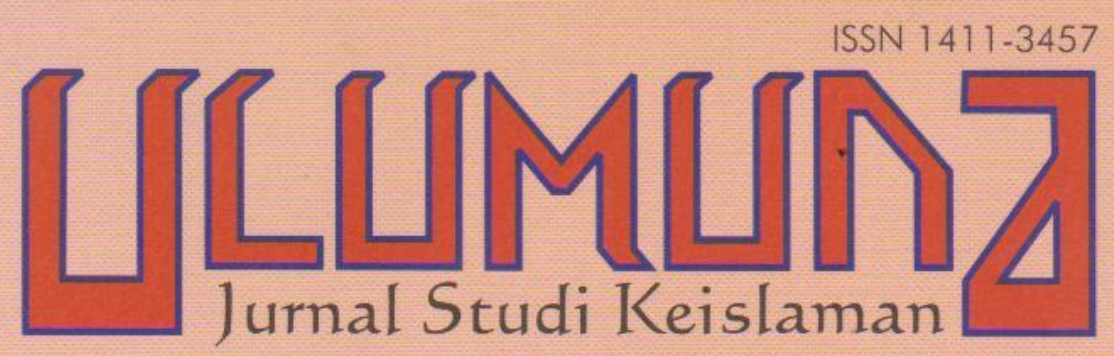

Volume XII• Nomor 1• Juni 2008

STUDI ANALITIS DIMENSI SACIFACT PENDIDIKAN ISLAM PADA MASA KEJAYAANNYA (750-1258 M) Abdul Fattah

AKTUALISASI MANUSIA VERSI AL-QUR'AN: ANTARA IDEALITAS DAN REALITAS PENDIDIKAN ISLAM Ismail Thoib

PENDIDIKAN ISLAM DAN PENCERAHAN SPIRITUALITAS: IKHTIAR MENJAWAB TANTANGAN POSMODERNISME Suparta

LESSON STUDY DALAM PEMBELAJARAN AGAMA ISLAM DI SEKOLAH UMUM Ahmad Munjin dan Khoirul Adib

STUDI PERUBAHAN KELEMBAGAAN DAN METODOLOGI PADA MADRASAH MODEL Taufik Churahman dan Musfigon POSISI PEREMPUAÑ
PERSPEKTIF ULAMA KLASIK
Baehaqi 


\section{PEDOMAN TRANSLITERASI}

\begin{tabular}{|c|c|c|c|}
\hline Arab & Latin & Arab & Latin \\
\hline 1 & $=$ & ف & $=\mathbf{f}$ \\
\hline ب & $=$ & ق & $=\mathrm{q}$ \\
\hline$\dot{H}$ & ts & ك & $=\mathbf{k}$ \\
\hline ج & $=$ & $J$ & $=1$ \\
\hline$\tau$ & $=$ & b & $=\mathrm{m}$ \\
\hline$\dot{\tau}$ & $=\quad \mathrm{kh}$ & $\dot{0}$ & $=\mathbf{n}$ \\
\hline$د$ & $=$ & و - - - 1 & $=\mathbf{w}$ \\
\hline$\dot{j}$ & $\mathrm{dz}$ & • & $=h$ \\
\hline$\jmath$ & $=$ & $\&$ & $=$, \\
\hline j & $=$ & ي & $=y$ \\
\hline س س & $=$ & & \\
\hline ش & $=$ & \multirow{2}{*}{\multicolumn{2}{|c|}{$\begin{array}{l}\text { Untuk Madd } \\
\text { dan Diftong }\end{array}$}} \\
\hline ص & sh & & \\
\hline ض & dl & i & $=$ â (a panjang) \\
\hline b & th & إين & $=\hat{\mathbf{1}}(\mathbf{i}$ panjang) \\
\hline ظ & $\mathrm{zh}$ & أوْ & $=\quad \hat{\mathbf{u}}$ (u panjang) \\
\hline$\varepsilon$ & $=$ & 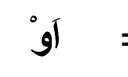 & $=a w$ \\
\hline$\dot{\varepsilon}$ & $=g h$ & آين & $=$ ay \\
\hline
\end{tabular}




\section{ISI}

TRANSLITERASI

ANTARAN

UTAMA

Abdul Fattah

Studi Analitis Dimensi Sacifact Pendidikan Islam pada Masa Kejayaannya $(750-1258 \mathrm{M}) \bullet 1-28$

Ismail Thoib

Aktualisasi Manusia Versi Al-Qur'an:

Antara Idealitas dan Realitas

Pendidikan Islam • 29-46

Suparta

Pendidikan Islam dan Pencerahan

Spiritualitas: Ikhtiar Menjawab Tantangan

Posmodernisme • 47-66

Ahmad Munjin Nasih Lesson Study dalam Pembelajaran

dan Khoirul Adib Pendidikan Agama Islam

di Sekolah Umum • 67-88

Taufik Churahman Dinamika Pendidikan Islam: Studi

dan Musfiqon

Perubahan Kelembagaan dan Metodologi

pada Madrasah Model • 89-106

LEPAS

Mutawalli Pembaruan Hukum Islam:

Menimbang Tawaran Pemikiran

'Abd al-Lâh al-Na'îm • 107-128

Baehaqi Posisi Perempuan

Perspektif Ulama Klasik • 129-142

Ahmad Sulhan Islam Kontemporer: Antara Reformasi

dan Revolusi Peradaban • 143-156

Ahmad Choirul Rofiq Menilai Kompetensi al-Mâturîdî di Bidang

Tafsir al-Qur'an • 157-182

ULAS BUKU

Yayuk Fauziyah Menyingkap Kuasa Maskulinitas di Balik

Tabir Feminitas Wanita Jawa • 183-200

INDEKS 


\title{
STUDI ANALITIS DIMENSI SACIFACT PENDIDIKAN ISLAM PADA MASA KEJAYAANNYA (750-1258 M)
}

\author{
Abdul Fattah*
}

\section{Abstract}

Many islamic education institutions have emerged since the times of Prophet Muhammad. From historical perspective of classical Islam, the period of Abbasiate (750-1258) was the peak periode of their development. Applying sacifact analysis, this article is aimed at uncovering multi historical aspects of the institutions development. George Makdisi and Anmad Syalabî have classified the development into two periods, premadrasah and post-madrasah. The former was considered as a milestone in the history of islamic education. The transformation proccess from masjid to madrasah went through three phases of transformation, i.e. phase of masjid, phase of masjid khân, and phase of madrasah. In addition, there were three factors accelerating the transformation process. Firstly, the educational activities in masjid were considered overlap their main function as worship building. Secondly, the need for science and knowledge emerged rapidly. And thirdly, there was new orientation in managing good education for muslim society.

Keywords: Institusi Pendidikan Islam, Periode Pramadrasah, Periode Pascamadrasah, Transformasi Pendidikan, Madrasah.

PADA masa awal perkembangan Islam, penyelenggaraan pendidikan Islam secara formal yang sistematis belum terlaksana. Pendidikan yang berlangsung umumnya masih bersifat informal. Ini pun lebih berkaitan dengan upaya-upaya dakwah islamiyah,

*Penulis adalah dosen tetap Fakultas Tarbiyah IAIN Mataram. email: fath_smart@yahoo.com 
berupa penyebaran dan penanaman dasar-dasar kepercayaan dan ibadah Islam. Dalam kaitan itulah, dapat dipahami kenapa proses pendidikan Islam pertama kali berlangsung di rumah sahabat tertentu; yang paling terkenal adalah Dâr al-Arqâm. Ketika masyarakat Islam telah terbentuk, pendidikan Islam kemudian diselenggarakan di masjid. Proses pendidikan di kedua tempat ini, dalam penilaian Azyumardi Azra, dilakukan dalam balaqah atau lingkaran belajar. ${ }^{1}$ Pendidikan formal dalam Islam, baru muncul pada masa belakangan, yakni pada periode kebangkitan madrasah.

Artikel ini akan berupaya mendeskripsikan dimensi sacifact dalam sejarah pendidikan Islam pada masa kejayaannya (750$1258 \mathrm{M}$ ) atau Abad Pertengahan (dalam konteks sejarah pendidikan Islam) pasca Daulah 'Umaiyyah di Damaskus, berdasarkan data dan fakta sejarah yang terdapat dalam berbagai literatur.

\section{Perkembangan berbagai Institusi Pendidikan Islam}

Dalam sejarah pendidikan Islam, dikenal banyak sekali institusi dan pusat pendidikan dengan jenis, tingkatan, dan sifatnya yang khas. A $\underline{\text { hmad Syalâbî, }}$, Muhammad 'Atiyyah alAbrashî, ${ }^{3}$ Muhammad Munîr Mursî, ${ }^{4}$ Muhammad Munîr Sa'îd alDîn, ${ }^{5}$ Hisyam Nasabe, ${ }^{6}$ Mehdi Nakosten, ${ }^{7}$ George Makdisi ${ }^{8}$

${ }^{1}$ Azumardi Azra, Pendidikan Islam Tradisi dan Modernisasi Menuju Islam Modern (Jakarta: LOGOS, 1999), vii.

${ }^{2}$ Ahmad Syalîbî, Târikeh al-Tarbiyyah al-Islâmiyyah (Kairo: Maktabah alEnglo al-Misriyyah, 1960), 33-86.

${ }^{3}$ Muhammad 'Atiyah al-Abrasyî, Al-Tarbiyyah al-Islamiyyah (t.k.: Dâr alQawmiyyah, 964), 45-60.

${ }^{4}$ Muhnammad Munîr Mursî, Al-Tarbiyyah al-Islâmiyyah; Ushûluha wa Tashawnuruha fí al-Bilad al-'A rabiyyah (Kairo: 'Alim al-Kutub, 1977), 91-110.

${ }^{5}$ Muhammad Munîr Sa'îd al-Dîn, Dirâsât fî Tarîkh al-Muslimîn (Libanon: Beirut, 1995), 30-57.

'Hisyam Nasabe, Muslim Educational Institution (Beirut: Riyadh Solh Square, 1989), 13-26. 
menyebutkan institusi-institusi tersebut sebagai berikut; al-Buyut, al-Kuttâb, al-Qusûr, Hawânît al-Warrâqîn, Manâzil al- Ulamâ', alSalûnât al-Adabiyyah, al-Bâdiyah, Zâwiyah dan Khânaqah (Ribât), dan al-Madrasah. Kemudian Ahmad Syalabî ${ }^{9}$ dan George Makdisi10 mengklarifikasikan institusi-institusi tersebut menjadi dua periode, yaitu periode pramadrasah dan periode pascamadrasah. Dengan demikian, madrasah dianggap tonggak baru dalam penyelenggaraan pendidikan Islam. ${ }^{11}$

\section{Institusi Pendidikan Islam Pramadrasah}

Ahmad Syalabî dalam magnum opus-nya al-Tarbiyyah: Nuzumubâ, Falsafatubâ, wa Târîkhubâ, menilai bahwa institusiinstitusi pendidikan Islam sebelum periode madrasah tersebut tetap dipakai sesuai dengan sifat tradisionalnya, sekalipun jumlah dan peminatnya sedikit. Beberapa institusi tersebut akan dideskripsikan secara sederhana, sesuai dengan perkembangan yang dapat teramati, terutama dimulai pada masa Daulah 'Abbâsiyah berkuasa di 'Irak, sehingga tidak terjadi overlapping dengan pembahasan yang mirip sebelumnya.

\section{Al-Qusûr (Pendidikan Rendah di Istana)}

Pendidikan anak di istana-istana berbeda dengan pendidikan anak-anak pada umumnya. Di istana, metode pendidikan dasar ini dirancang oleh orang tua murid (pada khalifah dan pejabat) agar selaras dengan tujuannya, sesuai dengan minat dan kemampuan anaknya. Metode pembelajarannya pada garis

${ }^{7}$ Mehdi Nakosten, History of Islamic Origins in The Western Education (Colorado: Colorado University Press, 1964), 37-53.

${ }^{8}$ George Makdisi, The Rise of Colleges: Institution of Learning in Islamic and West (Edinburgh: Edinburgh University Press, 1981), 9-32.

'Syalabi, Târîkh ..., 33.

${ }^{10}$ Makdisi, The Rise ..., 10 dan 27.

${ }^{11}$ Maksum, Madrasah Sejarah dan Perkembangannya (Jakarta: LOGOS, 1999), 52 . 
besarnya sama dengan metode yang diterapkan kepada anakanak lain di kuttâb, hanya terkadang ditambah atau dikurangi menurut para pembesar yang bersangkutan dan selaras dengan keinginan untuk menyiapkan anak mereka secara khusus untuk menghadapi kehidupannya yang akan datang. Sebutan untuk pengajarannya bukan lagi mu'allim sibyân atau mu'allim kuttâb, tetapi mu'addib. Para mu'addib tersebut diberikan tempat tinggal di istana, dan mereka tetap mengajarkan ilmunya, terutama berkaitan dengan pengayaan wawasan dan peradaban seputar alQur'an, hadis, sya'ir, dan berbagai lintasan peristiwa. Anak-anak belajar di dalamnya, sehingga melewati masa kanak-kanaknya. Selanjutnya, mereka beralih dari siswa kuttâb ke tingkat mahasiswa di halaqât, masjid, atau madrasah. ${ }^{12}$

Sistem pendidikan ini telah berlangsung dari Daulah 'Umâiyyah sampai Daulah 'Abbâsiyyah. Hârûn al- Rasyîd tercatat sebagai khalifah yang memiliki metode pendidikan dan pembelajaran yang lebih baik (dari segi metodologi pembelajaran) bila dibandingkan dengan metode yang diberikan oleh wali murid yang lain. ${ }^{13}$

\section{Al-Kuttâb}

Tujuan utama dari keberadaan al-Kuttâb ini adalah sebagai tempat menghafal dan mengjarkan al-Qur'an beserta penulisannya. Sebab menghafal al-Qur'an tidaklah mudah, kecuali dengan mempelajarinya. Diisyaratkan dalam mengajarkannya adalah adanya kualitas tartîl (bacaan) yang baik. Ketika peserta didik telah memiliki pengetahuan yang baik tentang al-Qur'an, maka selanjutnya mu'allim al-kuttâb tersebut mengajarkan mereka 'ibarat-ibarat dalam ilmu nahwu dan ilmu

${ }^{12}$ Syalabi, Târîkh..., 46-8.

13Rusman Thoyyib, Development of Muslim Educational System in The Classical Period 600-1100 A.D.: An Over View, ed. Ahmad Minhaji et. al., The Dinamic of Islam Civilization (Yogyakarta: Titian Illahi, 1998), 61. 
bahasa lainnya. Terkadang juga diajarkan ilmu hitung, sejarah, dan hal-hal yang terjadi pada bangsa Arab dahulu kala. Keseluruhan kurikulum pembelajaran lebih ditekankan pada aktivitas menghafal (memory work). ${ }^{14}$ Keseluruhan aktivitas pembelajaran tersebut umumnya berlangsung sejak hari Sabtu sampai hari Kamis dengan pengecualian hari Jum'at dan pertengahan kedua hari Kamis. ${ }^{15}$

Pada periode 'Abbâsiyyah, terjadi perubahan berkaitan dengan manajemen keuangan penyelenggaraan pendidikan. Pembayaran terhadap aktivitas pengajaran diberikan sebagai sesuatu yang lazim atas waktu dan energi yang diberikan dan dikorbankan oleh para penyayang anak tersebut. Pemberian motivasi dan dukungan kepada para mu'allim al-kuttâb tersebut mengindikasikan adanya perubahan orientasi kaum muslim dari yang bersifat spiritualis menjadi materialis. Keadaan itumenurut Rusman Thoyyib_-dapat dilihat sebagai konsekuensi alamiah dari pengaruh asing yang cukup intensif merembes dan berkembang dalam dunia Islam, terutama dari orang Persia dan bersumber juga dari bahasa dan budaya orang Yunani. ${ }^{16}$

Khusus perkembangannya di Spanyol sebagaimana dikemukakan Khaldûn bahwa penduduk Spanyol ketika itu telah memiliki metode tersendiri dalam mengajarkan anak-anak. Selain itu, materi pembelajaran yang dipergunakan tidak terbatas pada al-Qur'an saja, tetapi mereka menambahkannya dengan riwayatriwayat sya'ir, teknik korespondensi, tata bahasa Arab, dan seni menulis indah (khat). Bahkan perhatian mereka terhadap seni tulis menulis indah itu, jauh lebih besar bila dibanding dengan keseluruhan materi yang diajarkan. Berbeda dengan penduduk Afrika yang mencampurkan materi al-Qur'an dan hadis secara umum (di samping adanya al-'Ulûm al-Diniyyah yang lain). Hanya

${ }^{14}$ Philip K. Hitty, History of The Arabs (London: The MacMillan Press, 1974), 408.

15Mursî, Al-Tarbiyyah..., 95-6.

16Thoyyib, Development..., 61. 
saja perhatian mereka kepada al-Qur'an, terutama aspek perbedaan periwayatan dan cara membacanya lebih besar bila dibandingkan dengan materi lainnya. ${ }^{17}$

\section{Hawânit al-Warâqîn}

Sejak permulaan Daulah 'Abbâsiyyah, toko-toko buku sebagai agen komersial dan sekaligus berfungsi sebagai center of learning telah bermunculan. ${ }^{18}$ Kemudian menyebar dengan cepat di berbagai ibukota dan negara yang di luar negeri Islam. ${ }^{19}$ Umumnya, para penjual buku itu adalah orang yang memiliki tulisan yang bagus, pandai menyalin tulisan, dan menguasai literatur yang ada. Biasanya mereka juga menggunakan tokonya tidak hanya sebagai studio dan tempat berdagang. Tetapi pada saat bersamaan, toko tersebut difungsikan sebagai pusat diskusi tentang berbagai karya sastra bagi para cendekiawan dan pujangga. ${ }^{20}$ Para pemilik toko-toko (warrâqûn) tersebut menulis karya monumental, kemudian menawarkannya kepada orang yang tertarik kepadanya. ${ }^{21} \mathrm{Di}$ antaranya adalah Ibn al-Nadîm (995 M) yang telah menulis kitab Fibrisât,22 'Ali Ibn 'Isâ telah menulis bermacam-macam kitab, dan Yâqût al-Hamawî telah menulis Mu'jam al-Udabâ' dan Mu'jam al-Buldân. ${ }^{23}$

\section{Manâzil al-'Ulamâ'}

Di antara rumah ulama terkenal yang menjadi tempat belajar adalah rumah Ibn Sînâ untuk memperdalam dan mempertajam

17‘Abd Raḥmân Ibn Khaldûn, Muqaddimah Târîkh Ibn Khaldûn (Beirut: Dâr al-Fikr, 1988), 740-3.

${ }^{18}$ Hitty, History..., 414.

${ }^{19}$ Syalabî, Târîk...., 66.

${ }^{20}$ Hitty, History..., 414.

${ }^{21} \mathrm{J.J}$. Sunders, A History of Medievel Islam (London dan New York: Routledge, 1996), 189.

${ }^{22}$ Nakosten, History..., 29-32.

${ }^{23}$ Syalabî, Târîkh..., 51. 
wawasan tentang Kitâb al-Shifâ' dan al-Qanûn, rumah Imâm Ghazâlî untuk mengkaji Kitâb Ibyâ' Ulûm al-Dîn, rumah 'Abû Sulaymân al-Sijistânî untuk memperdalam wawasan masa lampau dan tempat berlangsung diskursus tentang berbagai topik. Begitu juga dengan rumah 'Ali Muhammad Ibn al-Fasîhî dan rumah Ya'qûb Ibn Kalîs (salah seorang wazir khalifah al'Azîz bi Allah al-Fâtimî) untuk mengetahui, memperdalam, dan mendiskusikan mazhab Syi'ah Ismâiliyyah.

Dipergunakannya rumah-rumah ulama dan para ahli tersebut karena terpaksa dan dalam keadaan darurat. Ini dapat diambil contoh, misalnya rumah Imâm Ghazâlî yang didatangi oleh murid-muridnya setelah berhenti mengajar di madrasah Nizâmiyah di Naysabur dan melakukan perjalanan untuk ibadah haji dan melakukan i'tikaf di masjid jami' 'Umâwî di Damaskus. Di sini kemudian, ia menulis kitab yang terkenal bernama I $\underline{b} \hat{a}{ }^{\prime}$ 'Ulùm al-Dîn. ${ }^{24}$

\section{Al-Salûnât al-Adabiyyah}

Pendirian majlis sastra ini dimaksudkan sebagai tempat khusus yang diadakan oleh khalifah untuk membahas berbagai macam ilmu pengetahuan. Majlis ini bermula sejak zaman Khulafâ' al-Râsyidûn yang lazimnya memberikan fatwa dan bermusyawarah serta berdiskusi dengan untuk memecahkan berbagai permasalahan dengan mengambil tempat di luar masjid. Pada masa Dinasti 'Umaiyyah, majlis ini dipindahkan ke istana dan orang-orang yang berhak menghadirinya hanyalah orangorang tertentu saja yang diundang oleh khalifah yang disertai dengan etika tertentu. ${ }^{25}$

Pada masa 'Abbasiyah, di majlis ini sering diadakan perlombaan antara para penya'ir, fuqaha, dan diskusi para sarjana dalam berbagai disiplin ilmu. Termasuk juga diadakan

${ }^{24}$ Ibid, 74.

25Ibid, 62-7. 
sayembara di antara ahli kesenian dan para pujangga sehingga institusi ini cukup produktif dan kondusif untuk pengembangan ilmu pengetahuan dan kebudayaan. Pada masa Hârûn al-Rasyîd, terdapat sejumlah tokoh terkenal yang aktif menghadiri forum dalam institusi ini, di antaranya: 1) dari kalangan penyair; Abû Nuwâs, Abû al-'Itâhiyah, Muslim ibn al-Walîd, dan al-'Abbâs ibn al-Ahnnâf; 2) dari kalangan musisi; Ibrâhîm al-Mawsalî dan anaknya yang bernama Ishâqq; 3) dari kalangan ahli gramatika; Abû 'Ubaydah, al-Kisầî, Ibn al-Simân al-Wâ'iz dan al-Waqidî.

\section{Al-Masjid dan al-Jâmi’}

Para sejarah muslim membedakan dua terma yang melekat dan mengacu kepada arti masjid. Pertama, masjid adalah terma yang digunakan untuk menunjuk kepada arti masjid yang yang berukuran kecil sebagai tempat melaksanakan shalat lima waktu seperti biasa. Kedua, jâmi' adalah terma masjid yang berukuran besar dan memiliki tiang sandaran yang lebar dan luas di mana tidak hanya shalat lima waktu saja yang diselenggarakan di dalamnya, tetapi juga shalat Jum'at dan dua shalat Ied. Selain itu, ia merupakan pusat dan urat nadi untuk berbagai aktivitas keagamaan, politik, kebudayaan, kemasyarakatan, dan penyelesaian urusan yudikatif. ${ }^{26}$

Menurut Makdisi, jâmi' merupakan terma eleptik yang asalnya adalah kata sifat dari frase masjid jami', yaitu masjid agung yang menyatukan seluruh jama'ah dalam meningkatkan keimanan melalui shalat Jum'at atau shalat Ied. Perbedaan terma tersebut terlihat secara jelas pada abad $\mathrm{V} \mathrm{H} / \mathrm{XI} \mathrm{M}$, yang diletakkan dengan Teori Konstitusional al-Mawardi (w. 450 H/1058 M). ${ }^{27}$

Pada masa awal dakwah islamiyyah, masjid memiliki fungsi edukatif yang sangat penting, di samping sebagai markâz aktivitas politik, sosial, budaya, dan agama. Pada perkembangan

${ }^{26}$ Mursi, Al-Tarbiyyah..., 93.

${ }^{27}$ Makdisi, The Rise ..., 12. 
berikutnya, para penganut mazhab, aliran, dan sekte berbeda, berkumpul di masjid dan menyampaikan materi pelajaran sesuai dengan mazhab masing-masing. Dan materi pembelajarannyapun meluas, yang semula terbatas pada materi keagamaan berupa al-Qur'an, tafsir, dan hadis. Pada tahap berikutnya diajarkan juga ilmu kalam, fiqh, filsafat, nahwu, sastra, sejarah, ilmu hitung, ilmu falaq, kedokteran, dan ilmu-ilmu kealaman. ${ }^{28}$

Seperti halnya masjid, pada masa ini juga bermunculan dan berkembang jâmi' sebagai pusat pendidikan, hanya saja perkembangannya sedikit lamban dibanding dengan masjid. Beberapa jâmi' yang terkenal, termasuk sebelum masa Dinasti 'Abbâsiyyah, adalah: Jâmi' 'Amr. Jâmi' ini dibangun oleh 'Amr Ibn al-'Âsh pada tahun $21 \mathrm{H}$, kemudian mengalami renovasi setelah itu berkali-kali. Pada mulanya, Sulayman Ibn 'Atr alTâjibî telah membuat majlis untuk memberikan pencerahan kepada masyarakat dengan metode pemberian kisah-kisah. Kemudian selain kisah tersebut, permasalahan-permasalahan yurisprudensi diberikan juga, meskipun kemudian kembali seperti semula (hanya diberikan qissah saja). Aktivitas tersebut telah dimulai sejak tahun $38 \mathrm{H}$ dan sejak saat itulah masjid jâmi' ini telah menjadi pusat kebudayaan dan mahkamah peradilan. ${ }^{29}$

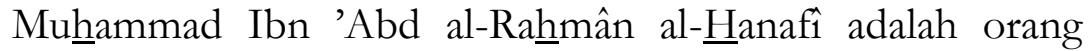
yang mengetahui banyak tentang masjid ini, di mana pada tahun 749 H menjamurnya balaqah yang jumlahnya mencapai 40-an untuk mengkaji pelbagai jenis ilmu pengetahuan. Di jâmi' ini juga terdapat Zâwiyyah Imâm Syâfì yang cukup terkenal yang terletak di daerah tepian kota Sandubis yang merupakan wakaf Sultân alMâlik al-Azîz Usmân Ibn Salâh al-Dîn. ${ }^{30}$

Jâmi' Damaskus. Masjid jâmi' yang dibangun pada Dinasti 'Umaiyyah oleh al-Walîd Ibn 'Abd al-Mâlik ini, berbeda dengan jâmi' yang terdapat di Baghdad, bila ditinjau dari keberadaan

${ }^{28}$ Mursi, Al-Tarbiyyah..., 91.

${ }^{29}$ Ibid., 91.

${ }^{30}$ Ibid., 92. 
institusi pendidikan yang terdapat di dalamnya. Nu'aymî, telah memperinci institusi yang terdapat di jâmi' ini yang di dalamnya terdapat halaqah, mi'ad, tashdîr, sab's, dan zâwiyah. Zâwiyah yang terdapat di masjid jâmi' 'Umaiyyah ini memiliki fungsi hampir sama seperti madrasah. Terdapat 8 buah zâwiyah saat itu; 2 bermazhab Syâfi'î, 1 Hambalî, 3 Hanafî, 1 Malikî, dan sisanya didesain dengan nama al-Syaykhiyya yang diambil dari nama Ibn Syaykh al-Islâm. Di antara zâwiyah yang 8 ini, terdapat 1 di antaranya bernama al-Ghazzâliyah, yang diberi nama setelah Imâm al-Ghazâlî (w. 505 H/1111 M) mengajar hukum Islam dalam mazhab Syâfi'î. Itu dilakukannya segera setelah meninggalkan Nizâmiyyah di Baghdad (w. 484-8 H/1091-5 M). ${ }^{31}$

Jâmi’ al-Az̧har. Al-Azhar mula-mula didirikan sebagai masjid jâmi' oleh seorang panglima Fâtimiyyah, Jawhar al-Siqilî, kelahiran Sicilia, setelah Mesir pada tahun 969 M/354 H secara penuh dikuasainya. ${ }^{32}$ Semula ia merupakan lembaga Fâtimiyyah sebagai pusat pelatihan kader dakwah untuk menyebarluaskan doktrin Isma'iliyyah. ${ }^{33}$ Untuk memenuhi kebutuhan terhadap para da'i ini, al-Azhar kemudian ditingkatkan peranannya, bukan hanya sebagai masjid, tetapi juga sebagai lembaga pendidikan yang terorganisir di bawah pengawasan khalifah, tepatnya dimulai sejak tahun 378 H. ${ }^{34}$ Berangsur-angsur sejak tahun 975996 M, dijadikan universitas oleh Khalifah al-'Azîz. ${ }^{35}$ Semenjak itu sampai kini, jâmi' tersebut telah menjadi sebuah jâmi'ah (perguruan tinggi) dan termasuk dari perguruan tinggi pertama di dunia Islam. ${ }^{36}$

${ }^{31}$ Ibid., 93.

${ }^{32}$ Syalabî, Târikkh..., 87.

${ }^{33}$ Cyril Glasse, Ensiklopedi Islam Ringkeas, ter. Ghifran A. Mas'adi (Jakarta: Raja Grafindo Persada, 1999), 44.

${ }^{34}$ Harun Nasution, Ensiklopedi Islam Indonesia (Jakarta: Djambatan, 1992), 144.

35Ibid.,114

36Syalabî, Târîkh ..., 87-8. 
Dalam institusi ini, Bani Fâtimiyyah menekankan pengajaran yang bersifat filosofi-teologis. ${ }^{37}$ Dalam analisis historis Bilgrami dan Ashraf, institusi ini memiliki 3 macam kelas, yaitu: 1) kelaskelas untuk beberapa kelompok orang yang datang ke Azhar untuk mendengarkan al-Qur'an dan penafsirannya; 2) kelas-kelas untuk para mahasiswa Universitas al-Azhar yang ingin mendengarkan kuliah dari para dosen, mengajukan pertanyaan, dan mengkaji jawaban mereka; 3) kelas-kelas lain, di mana kuliah formal sering diberikan oleh pimpinan mubalig. Kuliah ini disebut dengan Majlis al- $\underline{\text { Hikam. }}$.

Hal penting yang perlu dicatat bahwa al-Azhar mempunyai andil yang cukup besar terhadap perkembangan lembaga pendidikan di Eropa. Pemakaian seragam sekolah, pengembangan tradisi perbantahan, penjurusan dua buah fakultas; Fakultas Graduate dan Undergraduate, berasal dari alAzhar. Selain itu, al-Azhar memiliki peranan yang sangat penting dalam mendorong pertumbuhan pendidikan yang lebih tinggi di dunia Islam. ${ }^{38}$

\section{Maktabât}

Menurut Syalabî, perpustakaan merupakan salah satu metode orang terdahulu dalam menyebarkan ilmu yang dikarenakan adanya keterbatasan kemampuan untuk memilih buku-buku yang harganya terlampau mahal. Atas dasar itu, mereka meminta bantuan kepada orang mencintai profesi mengajar, agar mendirikan sebuah perpustakaan di mana semua buku dikumpulkan dan pintu-pintunya dibukakan bagi mereka (yang memerlukan), seperti yang terjadi di Perpustakaan Iskandariyyah dan Bayt al-Hikmah pada masa Daulah 'Abbâsiyyah. ${ }^{39}$ Pada perkembangan berikutnya, perpustakaan telah menjadi salah satu

${ }^{37}$ Ibid., 87-8.

${ }^{38}$ Glasse, Ensiklopedi..., 44.

${ }^{39}$ Syalabî, Târîkh..., 15. 
pusat pendidikan dan kebudayaan Islam. ${ }^{40}$ Umumnya, perpustakaan ini bukan tempat mengajarkan secara teratur disiplin ilmu tertentu. ${ }^{41}$ Sebab, yang menjadi fokus dan konsentrasi utama adalah kegiatan research akademik, sedangkan mengajar merupakan fungsi keduanya. ${ }^{42}$

Pada masa 'Umaiyyah, perpustakaan ini tidak mendapat perhatian yang cukup besar bila dibandingkan dengan 'Abbâsiyyah. Pada masa 'Abbâsiyyah, perpustakaan telah menyebar dengan luas seiring dengan meluasnya penggunaan kertas sebagai intrumen penulisan kitab-kitab dan munculnya para penulis kertas yang sangat mahir, serta meluasnya lingkaran belajar ( halaqah) para cendekiawan dan sastrawan. ${ }^{43}$ Pada masa itu, terkenal 3 jenis perpustakaan, yaitu: ${ }^{44}$ Pertama, Perpustakaan Umum (Perpustakaan Publik). Perpustakan ini dibangun berdekatan dengan masjid agar mudah dijangkau oleh berbagai kalangan ketika hendak belajar di dalamnya untuk memperoleh ilmu pengetahuan. Pada perkembangan berikutnya-terutama setelah menjamur dan meluas-ia dibangun menyatu dengan sekolah-sekolah (madâris).45 Perpustakaan jenis ini memiliki jumlah yang sangat banyak. Bahkan pada saat itu, sukar dijumpai masjid atau madrasah tanpa dilengkapi dengan kompilasi bukubuku yang nantinya dikunjungi oleh mahasiswa dan peneliti (researcher). Sebagai contoh di sini adalah Bayt al-Hikmah yang dibangun oleh khalifah Hârûn al-Rasyîd dan mengalami perkembangan pesat pada masa al-Ma'mûn (830 M).

Perpustakaan ini mendapat perhatian khusus oleh al-Ma'mûn sebagai khalifah yang luas wawasan peradabannya, berpikir bebas, mencintai pengetahuan, dan kesusastraan. Hasil yang

\footnotetext{
${ }^{40}$ Mursi, Al-Tarbiyyah..., 102.

${ }^{41}$ Makdisi, The Rise ..., 24.

${ }^{42}$ Nashabe, Muslim..., 20.

${ }^{43}$ Mursi, Al-Tarbiyyah..., 102.

${ }^{44}$ Syalabî, Târîkh..., 14 dan Nakosten, History..., 45.

45Ibid., 148.
} 
dapat terlihat dan dirasakan berikutnya adalah berkembangnya peradaban umat Islam, terjadi penetrasi al-ulûm al-ajnâbiyyah (ilmu-ilmu asing) yang pada titik klimaksnya, ia dipelihara dan dikembangkan oleh umat Islam. ${ }^{46}$ Selain itu, ia menjadi pusat penerjemahan, pentransmisian, penulisan, research, penyusunan buku, dan kegiatan ilmiah lainnya. Dari penemuan-penemuan yang pernah ada dalam lembaga ini, misalnya, al-Khawârizmî (Munhammad Ibn Mûsâ, w. 232 H/ 846 M) telah menemukan ilmu al-Jabar (geometri). Begitu juga Abnâ' Mûsâ Ibn Syâkir telah membuat analogi untuk Khâlifah al-Ma'mûn tentang luasnya bumi dengan jalan mengkiaskan lingkaran/rotasi siang hari di gurun pasir Sanjar. Dalam penilaian para ilmuan saat itu, hasil karyanya telah mendekati panjang dan luas bumi yang sebenarnya.

Institusi ini merupakan perpustakaan terbesar yang pernah ada pada masa 'Abbâsiyyah. Sebab ia berisi kitab-kitab tentang ilmu-ilmu agama Islam dan bahasa Arab, berbagai ilmu pengetahuan yang telah berkembang pada masa itu, serta berbagai buku terjemahan dari bahasa Yunani, Persia, India, Qibty, dan Aramy. Namun kebesarannya berakhir setelah Baghdad dihancurkan oleh Tentara Mongol di bawah Kaisar Hulagu pada tahun $1258 \mathrm{M} / 656 \mathrm{H}$ dan seluruh isinya dibuang ke sungai Tigris dan Eufrat. ${ }^{47}$ Contoh lain dari perpustakaan

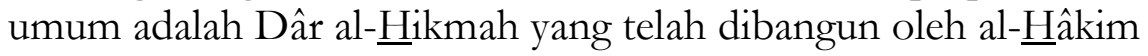
Ibn Amr al-Lâh dari dinasti Fâtimiyyah di Kairo pada hari Sabtu, tanggal 10 Jumadil Akhir 395 H (1005 M). ${ }^{48}$ Persiapan yang telah dilakukan untuk membangun sebuah masterpiece ini cukup matang dan sangat serius, terutama untuk menghilangkan bayangan di setiap benak orang saat itu akan kemegahan Bayt al-Hikmah yang pernah dibangun sebelumnya di Baghdad dan mencapai

\section{${ }^{46}$ Ibid.}

47Al-Dîn, Dirâsât..., 95-6.

48Syalabî, Târîkh..., 156. 
kejayaannya pada masa al-Ma'mûn. ${ }^{49}$ Dan setelah selesai dibangun, ia merupakan tandingan yang terdapat di Baghdad, sehingga al-Maqriz, seperti dikutip Mursî, menggolongkannya ke dalam salah satu keajaiban dunia bahkan tidak memiliki tandingan di kota-kota Islam lainnya. ${ }^{50}$ Di dalam Dâr alterdapat 1.600.000 buku, bahkan ada yang mengatakan 2.000.000 buah buku dalam bidang fiqh, nahwu, lughah (sastra), hadis, tarikh, sejarah para raja (târikh al-mulukk), ilmu falaq, dan kimia. ${ }^{51}$ Di dalamnya juga terdapat buku-buku yang jarang dan langka yang pernah ditulis dalam berbagai disiplin ilmu dan sastra. Untuk bidang kedokteran saja terdapat 6.000 buku. Di perpustakaan ini juga terdapat peta geografis yang sangat teliti yang tertulis di atas sutera dan memuat gambar bumi beserta gunung-gunung, laut, kota-kota, dan sungai-sungainya. ${ }^{52}$

Kedua, Perpustakaan antara Umum dan Khusus (Perpustakaan Semi Publik). Perpustakaan ini didesain bukan umum, artinya tidak semua strata sosial yang diperbolehkan masuk ke dalamnya; tetapi juga bukan khusus, sebab pemiliknya bukan memaksudkan agar ia menjadi milik mereka semata. Untuk masuk ke perpustakaan ini memerlukan izin khusus. Bahkan filsuf populer sekelas Ibn Sînâ pun, hanya diperkenankan masuk setelah mendapat izin. Perpustakaan seperti ini dibangun oleh khalifah atau raja untuk menunjukkan kecintaan dan kedekatannya kepada ilmu pengetahuan. ${ }^{53}$ Syalâbî memberikan contoh untuk perpustakaan jenis ini adalah perpustakaan al-Nasr li Dîn al-Lâh (memerintah tahun 575-622 H) dan perpustakaan al-Musta'sim bi al-Lâh (menjadi khalifah

${ }^{49}$ Ibid., 156.

${ }^{50}$ Mursi, Al-Tarbiyyah..., 107.

${ }^{51}$ Abrasyi, Al-Tarbiyyah..., 80.

${ }^{52 M u r s i ̂, ~ A l-T a r b i y y a h . . ., ~} 107$.

${ }^{53}$ Syalabî, Târîkh...,159 dan Abrasyi, Al-Tarbiyyah..., 80. 
tahun $640 \mathrm{H}$ ) yang merupakan perpustakaan besar yang berisi bermacam literatur dalam jumlah yang besar. ${ }^{54}$

Ketiga, Perpustakaan Khusus (Perpustakaan Pribadi). Perpustakaan ini dibangun oleh para cendekiawan dan sastrawan untuk keperluan khusus (seperti research dan pengkajian). ${ }^{55}$ Perpustakaan jenis ini khusus dibangun dan diperuntukkan oleh para ulama dan para sastrawan sebagai standar dan marajii' (rujukan) yang harus dimiliki oleh setiap ilmuan, pemikir, peneliti, pengarang, hakim, dan tokoh ilmu pengetahuan lainnya. ${ }^{56}$ Contoh yang terkenal dari perpustakaan jenis ini adalah perpustakaan al-Fath Ibn Khâqan yang merupakan wazị khalifah Mutawakkil yang terbunuh bersamanya di Samara tahun 247 H. Selain itu, dikenal juga perpustakaan Hunayn Ibn Ishâaq (w. $264 \mathrm{H}$ ), perpustakaan Ibn al-Khashab (w. $567 \mathrm{H}$ ), perpustakaan Jamîl al-Dîn al-Qiftî (w. 646 H), dan perpustakaan al-Mubâsysyir Ibn Fâtik (w. 5 H). ${ }^{57}$

\section{Bîmâristât dan Mustasyfayât}

Al-Bîmâristân berasal dari bahasa Persia yang terdiri dua akar kata; "bimâr" berarti "orang sakit" dan "satan" berarti "rumah". Dengan demikian ia berarti rumah sakit. Dan terma ini tetap dipergunakan dan mengacu kepada tempat penyembuhan orang sakit, sehingga muncul istilah baru yang menggantikan posisinya, yaitu terma mustashfâ yang dibangun pertama kali pada tahun 1825 M di Mesir yang diberi nama Mustashfâ Ab̂ै Za'bal.58 Di tempat seperti bimâristân inilah studi tentang kesehatan berkembang dengan pesat. Institusi yang hampir sama dengan rumah sakit modern ini, sering memformulasikan peran ganda dan pelengkap, yaitu di samping sebagai tempat penyembuhan

\footnotetext{
${ }^{54}$ Ibid., 159-160.

${ }^{55}$ Nakosten, History..., 45.

${ }^{56}$ Abrasyî, Al-Tarbiyyah..., 80.

${ }^{57}$ Syalabî, Târîkh..., 165-9.

${ }^{58}$ Mursî, Al-Tarbiyyah..., 110.
} 
orang sakit, juga sekaligus berperan sebagai pusat untuk mengajarkan ilmu kesehatan. ${ }^{59}$ Kondisi ini telah terlihat sejak awal dibangun al-Bîmâristân dalam Islam oleh al-Walîd Ibn 'Abd al-Mâlik pada tahun $88 \mathrm{H}$ yang telah memainkan kedua fungsi tersebut. ${ }^{60}$

Ketika itu, setiap bîmâristân mempunyai ketua seorang dokter yang memberikan kuliahnya kepada mahasiswa kedokteran, memberikan izin praktik kesehatan bagi yang telah menyelesaikan pelajarannya, baik teoritis maupun praktis serta telah menulis risâlah dalam cabang ilmu kedokteran yang telah dipilihnya. Pada tahap selanjutnya, mahasiswa tersebut diberikan ijazah atau (predikat) diploma oleh profesor mereka. ${ }^{61}$ Pendidikan kedokteran ini telah terorganisir sedemikian rupa pada khilâfah' 'Abbâssiyyah. ${ }^{62}$ Selain daripada itu, rumah sakit juga termasuk salah satu institusi pendidikan yang penting. Sebab kebanyakan pengajaran ilmu kedokteran klinis, dilakukan di rumah sakit. Yang terjadi saat itu, aspek teoritis dari ilmu kedokteran diberikan secara mendalam di masjid atau madrasah. Sedangkan dimensi praktisnya, biasanya diajarkan dan dilakukan di rumah sakit yang banyak di antaranya telah memiliki perpustakaan dan sekolah yang memang secara khusus didesain untuk tujuan tersebut. ${ }^{63}$

Rumah sakit dibangun juga sebagai tempat khusus bagi dokter atau ia berada di bawah pengawasan khusus seorang dokter yang terkenal, seperti al-Râzî yang pernah ditempatkan dan bertugas mengepalai sebuah rumah sakit di mana ia bekerja dan mengajarkan murid-muridnya. Selain itu juga, Ibrâhîm Ibn Bakr mengatakan bahwa ia pernah mengajar ilmu kedokteran di

${ }^{59}$ Nasyabe, Muslim..., 25.

${ }^{60}$ Mursi, Al-Tarbiyyah..., 110 dan Thoyyib, Development..., 62.

${ }^{61}$ Ibid., 110-1.

${ }^{62}$ Seyyed Hossein Nasr, Science and Civilization in Islam (Amerika: the New American Library, 1970), 89.

63Ibid., 89. 
rumah sakit Adûdî yang dibangun oleh dinasti Buwayhid ('Adûd al-Dawlah ) sekitar abad V H/ XI M. ${ }^{64}$ Dari situlah kemudian rumah sakit berfungsi juga sebagai institusi pendidikan dan menjadi wahana pembantu bagi masjid atau madrasah di mana prinsip-prinsip dan pengetahuan teoritis dari filsafat kealaman beserta cabang-cabangnya (termasuk kedokteran) diajarkan. ${ }^{65}$

\section{Zâwiyah dan Khânaqah (Ribât)}

Akhirnya, di antara sekian banyak institusi pendidikan Islam pramadrasah, maka perlu juga mempertimbangkan pusat-pusat kaum sufi yang dalam bentuk tunggalnya disebut zâmiyah atau khânaqah. ${ }^{66}$ Setelah terjadi invasi Mongol tahun $1258 \mathrm{M}$, ternyata pusat-pusat sufi tersebut telah berfungsi lebih dari sekedar lembaga pendidikan yang berada di luar lembaga formal. Hal ini terlihat di wilayah Islam bagian timur, di mana terjadinya destruksi institusi-institusi eksternal masyarakat sebagai ekses yang dihasilkan dari invasi tersebut, tidak ada satu organisasi pun yang dapat memulai proses membangun kembali (restrukturisasi), kecuali melalui apa yang disebut dengan "gerakan masyarakat dalam masyarakat" di mana dalam konteks ini dapat dikatakan kelompok sufi berada di dalamnya. Terkadang sekali waktu, kewajiban untuk melestarikan hukum dan tata tertib serta upaya untuk melakukan justice enforcement terhadap segala bentuk kebrutalan dan kriminalitas berada di tangan kelompok sufi. Dari realitas tersebut, pusat-pusat sufi telah berubah menjadi sebuah institusi pendidikan, di mana di samping pengetahuan esotoris dan gnosis dari cabang-cabang seni dan pengetahuan yang sebelumnya diajarkan di madrasah dan masjid (jâmi'), kini telah menemukan tempat perlindungan. ${ }^{67}$

\footnotetext{
${ }^{64}$ Makdisi, The Rise ..., 27.

${ }^{65}$ Nasr, Science..., 89.

66Ibid., 90.

${ }^{67}$ Makdisi, The Rise ..., 20.
} 
Lebih jauh dapat diambil contoh, yaitu jâmi' Damaskus yang memiliki 8 buah zâmiyah; 2 mazhab Syâfi'î, 1 mazhab Hanbalî, 3 mazhab Hanafî, 1 mazhab Malikî, dan yang terakhir didesain atas nama al-Syaikhiyya. Kesemuanya merupakan pusat pengajaran pengetahuan tingkat tinggi (gnosis).

Berdasarkan perjalanan sejarah di atas, maka khânaqah harus dipertimbangkan juga sebagai salah satu institusi pendidikan yang penting dalam Islam. Itu bukan lantaran sejak awal ia merupakan tempat di mana pengajaran gnosis (bentuk tertinggi dari pengetahuan) diberikan, tetapi juga dalam penggal sejarah Islam berikutnya. Ia telah memulai dan mengisi fungsi sekolahsekolah masjid di berbagai penjuru dunia Islam (terutama di belahan timur). Dari sini dapat diketahui bahwa pusat sufi memainkan perannya bersamaan dengan jâmi', bîmâristân, dan mustashfâ sebagai salah satu institusi besar yang telah ikut bertanggung jawab terhadap pelestarian dan perkembangan pengetahuan dalam Islam. ${ }^{68}$ Begitulah sumbangsih institusi sufi dalam berupaya mencerahkan masyarakat Islam kala itu.

\section{Madrasah sebagai Lembaga Pendidikan Formal}

\section{Transformasi dari Masjid ke Madrasah}

Terdapat beberapa teori yang berkembang yng menjelaskan bagaimana proses transformasi lembaga dari masjid ke madrasah. Ahmad Syalabî dalam kapasitasnya sebagai serjana sejarah pendidikan Islam yang memberikan perhatian yang cukup intens terhadap sejarah kelembagaan madrasah, Syalabî mengemukakan pendapatnya, bahwa perkembangan lembaga pendidikan madrasah dari masjid terjadi secara langsung tanpa memakai lembaga perantara. ${ }^{69}$ Perkembangan madrasah ini dapat dikatakan sebagai konsekuensi logis dari semakin ramainya kegiatan pengajian masjid yang fungsi utamanya adalah sebagai

${ }^{68} \mathrm{Nasr}$, Science..., 90-1.

"99Syalabî, Târîkh...1960, 95-6. 
tempat ibadah. ${ }^{70}$ Syalabî memberikan ilustrasi lebih lanjut bahwa dengan perkembangan ilmu pengetahuan menyebabkan materimateri yang ada semakin menghendaki adanya dialog, debat, dan munaqâsyah, seperti ilmu kalam dan ilmu jadal. Sehingga ilmuilmu tersebut sangat berpotensi mengganggu pelaksanaan ibadah ritual di masjid. Sebab, di samping pelaksanaannya tidak lepas dari kegaduhan, juga minus ketenangan dan pemuliaan terhadap masjid. Atas dasar itu, agar tidak menggangu ketentraman dalam beribadah di masjid, maka untuk kegiatan pendidikan khusus dibuatkan tempat yang dikenal dengan nama madrasah. Namun dari penjelasan selanjutnya, kelihatannya masjid yang dimaksud adalah masjid yang telah mengalami modifikasi yang dilengkapi dengan serambi-serambi belajar dan tempat-tempat pemondokan, terutama bagi mereka yang datang dari jauh. Gambaran masjid seperti itu ternyata memiliki substansi yang sama dan menyerupai apa yang disebut Makdisi sebagai masjid Khân, ${ }^{71}$ merupakan masjid yang dilengkapi dengan bangunan, semacam asrama/pemondokan, yang disediakan bagi para pelajar dari luar kota untuk menghadiri kajian hukum Islam di masjid. Pada paruh awal abad IV H/X M, ditemukan masjid Khân yang dibangun oleh seorang pedagang dermawan Di'lij Ibn Ahmad Ibn Di'lij yang terletak di pasar kecil Ghâlib yang berdekatan dengan makam Suraij (konsultan hukum ternama dalam mazhab Syâfi'î).

Sementara itu, Makdisi dalam tulisannya tentang perkembangn madrasah dan institusi-institusi yang memiliki asal yang sama, mengajukan teori bahwa asal-muasal pertumbuhan madrasah merupakan sebuah muara dari 3 tahap, yaitu: pertama, tahap masjid. Tahap ini meliputi perkembangan pembelajaran di masjid yang difokuskan pada kajian hukum sebagai materi pokok. ${ }^{72}$ Tahap masjid ini berlangsung terutama pada abad VIII

${ }^{70}$ Ibid., 95.

${ }^{71}$ Makdisi, The Rise ..., 24.

${ }^{72}$ Ibid., 24-5. 
dan IX M. Masjid dalam konteks ini bukanlah masjid yang berfungsi sebagai tempat berjama'ah bagi seluruh penduduk kota yang biasa disebut dengan masjid jâmi' (Congregatual Mosque). Masjid seperti ini biasanya diatur oleh negara dan tidak terbuka untuk pendidikan agama bagi umum. Masjid yang dimaksud Makdisi sebagai tempat pendidikan adalah masjid biasa (masjid college) yang berfungsi di samping sebagai tempat jama'ah shalat, juga untuk majlis ta'lim (pendidikan). Di Baghdad pada masa itu terdapat beribu-ribu masjid dari jenis yang terakhir ini. Bahkan al-Ya'qûbî seperti yang dikutip Syalabî menyebut jumlahnya mencapai 30.000 buah. $^{73}$ Para penguasa seperti Adûd al-Dawlah (w. 965 M), al-Sâhib Ibn 'Abbâd (w. 995 M), dan Di'lîj alSijistânî (w. $965 \mathrm{M}$ ), merupakan pelopor yang mendukung perkembangan masjid untuk kepentingan pendidikan. ${ }^{74}$ Kedua, tahap masjid khân. Berbeda dengan masjid biasa, masjid Khân menyediakan tempat penginapan yang cukup representatif bagi para pelajar yang datang dari berbagai kota. Tahap ini mencapai perkembangan yang sangat pesat pada abad IV $\mathrm{H} / \mathrm{X} \mathrm{M}$. Menurut Makdisi, Badr Ibn Hasanawayh al-Kurdî (w. 1015 M) yang menjadi gubernur di beberapa wilayah di bawah kekuasaan' 'Adûd al-Daulah mendirikan 3000 masjid Khân. ${ }^{75}$ Selain itu, Abû Ishâaq, guru pada Nizâmiyah Baghdad, pernah aktif di masjid Khân yang ditempati oleh sekitar 10 atau 20 murid yang berguru kepadanya. ${ }^{76}$ Ketiga, tahap madrasah. Setelah perkembangan dua tahap di atas, maka muncul madrasah yang khusus diperuntukkan sebagai lembaga pendidikan. Madrasah dengan demikian menyatukan kelembagaan masjid biasa dengan masjid Khân. Kompleks madrasah terdiri dari ruang belajar, ruang pondokan, dan masjid. Menurut Makdisi, perkembangan madrasah dengan polanya yang utuh dan konkret dipelopori

\footnotetext{
${ }^{73}$ Syalabî, Târîkh..., 87.

${ }^{74}$ Ibid.

${ }^{75}$ Makdisi, The Rise ..., 24.

${ }^{76}$ Maksum, Madrasah..., 58.
} 
oleh Nizâm al-Mulk dengan madrasah Nizâmiyyah-nya tahun 459 H/1067 M. ${ }^{77}$ Hal ini bukan berarti bahwa Nizâm al-Mulk adalah orang yang pertama yang mendirikan madrasah dalam sejarah Islam abad Pertengahan. Yang perlu dicatat dalam konteks ini bahwa pembangunan madrasah Nizâmiyyah tersebut sangat mendorong pembangunan madrasah atau institusi pendidikan tinggi lainnya. ${ }^{78}$ Tidak berlebihan jika dikatakan bahwa pembangunan madrasah Nizâmiyyah menjadi pemantik tumbuh suburnya madrasah pada masa-masa sesudahnya.

\section{Faktor-faktor yang Mempengaruhi Transformasi dari Masjid ke Madrasah}

Terdapat sejumlah teori yang menjelaskan alasan dipertimbangkannya kembali masjid sebagai tempat pendidikan sehingga terjadi transformasi lembaga pendidikan dari masjid ke bentuk yang lainnya. Hal itu erat kaitannya dengan beberapa alasan berikut: pertama, kegiatan pendidikan di masjid dianggap telah mengganggu fungsi utama lembaga itu sebagai tempat ibadah. Syalabî menggambarkan hal tersebut sebagai berikut:

“... dari setiap group pertemuan, terdengarlah suara dari seorang guru yang memberikan pelajaran dan dari suara peserta didik yang bertanya dan saling berdebat. Maka terjadilah suara keras dari beberapa group pertemuan itu. Sedikit banyak hal tersebut menimbulkan gemuruh yang mengganggu pelaksanaan ibadah". ${ }^{79}$

Dalam pandangan al-Abrashî juga, anak kecil yang belajar di masjid kurang menjaga diri dari najis dan kotoran. Padahal tanqîh al-masajiid merupakan salah satu aspek yang sangat ditekankan oleh Rasul saw. ${ }^{80}$ Dengan dua pertimbangan tersebut, jelaslah

${ }^{77}$ Makdisî, The Rise ..., 31.

${ }^{78}$ Syzilowics, Pendidikan..., 83.

${ }^{79}$ Syalabî, Târîkh..., 95.

${ }^{80}$ Abrasyi, Al-Tarbiyyah..., 52. 
bahwa masjid menjadi semakin sulit untuk dijadikan tempat ibadah dan belajar dalam waktu yang bersamaan.

Kedua, berkembangnya kebutuhan ilmiah sebagai akibat dari perkembangan ilmu pengetahuan. Dengan berkembang ilmu pengetahuan, banyak ilmu yang tidak bisa sepenuhnya diajarkan di masjid. Kaitannya dengan hal ini, Syalabî mengatakan bahwa ilmu berkembang seiring dengan berkembangnya zaman, pengetahuan pun lebih maju lagi. ${ }^{81}$ Situasi demikian dapat dimengerti, sebab pada abad IV $\mathrm{H}$ (waktu yang dekat dengan berdirinya madrasah), gerakan pemikiran telah dan tengah berkembang dengan pesat. Apalagi setelah kegiatan penerjemahan buku-buku filsafat dan ilmu pengetahuan dari Yunani, India, Persia, dan China telah dilakukan secara sistematis dan serius sejak khalifah al-Mansûr (754-775 M) dan berkembang dengan luas sampai Hârûn al-Rasyîd (786-809 M) dan al-Makmûn (813-833 M). ${ }^{82}$ Dengan demikian, masjid kurang dipertimbangkan sebagai tempat utama pendidikan.

Ketiga, timbulnya orientasi baru dalam penyelengaraan pendidikan. Sebagian guru mulai berpikir untuk mendapatkan rejeki melalui kegiatan pendidikan. Dikatakan ada di antara pengajar yang pekerjaannya sepanjang hari memang mengajar, karena itu berusaha memperoleh penghasilan yang memadai. Untuk menjamin hal itu, dibangunlah lembaga lain seperti madrasah, karena jaminan seperti itu tidak mungkin diproleh di masjid.83 Dalam konteks ini, tidak mengherankan bila setelah dipisah dari masjid, peserta didik diberikan kewajiban membayar uang sekolah yang agak mahal. ${ }^{84}$

${ }^{81}$ Syalabî, Târîkh..., 95.

${ }^{82}$ C.A. Qadir, Philosophy and Science in The Islamic World (London: Routledge, 1990), 34-5.

83Syalabi, Târîkh..., 95-6.

${ }^{84}$ Bilgrami dan Ashraf, Konsep..., 34. 


\section{Awal Pelembagaan Pendidikan Secara Formal}

Al-Maqrizî berpendapat bahwa madrasah merupakan prestasi dan prestise abad V H. Madrasah pertama didirikan pada abad V H/XI M itu adalah madrasah Nizâmiyyah di Baghdad yang didirikan oleh Nizâm al-Mulk tahun 460 H/1067 M. Ia merupakan seorang negarawan Persia yang menjadi wazir Sultan Saljûq selama 30 tahun dalam pemerintahan Alp Arsalan dan Mâlik Syah antara tahun 1063-1092M/456-486 H. ${ }^{85}$ Banyak pula penulis lain yang berkesimpulan demikian, termasuk Ibnu Khallikân (w. 681 H/1282 M), Syalabî ${ }^{86}$ dan Makdisi. ${ }^{87}$ Bahkan Abdurrahîm Ghanîmah, sebagaimana dikutip Maksum, dalam karya monumentalnya al-Jâmi'ah al-Qubrâ, mengatakan bahwa terma "madrasah" belum dijumpai pada sumber-sumber sejarah hingga kira-kira akhir abad IV H.88

Hanya saja Azra dengan akurasi teropong kesejarahannya mengungkapkan bahwa dalam penelitian lebih akhir, misalnya yang dilakukan oleh Richard Bulliet mengungkapkan bahwa eksistensi madrasah-madrasah lebih tua di Nishapur, Iran. Pada sekitar tahun $400 \mathrm{H} / 1009 \mathrm{M}$ terdapat madrasah di wilayah Persia yang berkembang dua abad sebelum madrasah Nizâmiyyah. Yang tertua adalah Miyan Dahiya yang didirikan oleh Abû Ishâq Ibrâhîm Ibn Mahnûud di Nishapur. Lebih lanjut menurut Azra, pendapat ini didukung oleh sejarawan pendidikan Islam, Naji Makruf, yang mengatakan bahwa di Khurasan telah berkembang madrasah 165 tahun sebelum kemunculan madrasah Nizâmiyyah. ${ }^{89}$ Dengan mengutip pendapat Yâqût, Muhammad Munîr Saîd al-Dîn mengatakan bahwa Naysabur juga telah ada madrasah Ibnu Hibbân al-Tamîmî Abû Hâtim (w.

\footnotetext{
${ }^{85}$ Nasution, Ensiklopedi..., 742 dan Nakosten. History..., 38-9.

${ }^{86}$ Syalabi, Târikeh..., 98.

${ }^{87}$ Makdisi, The Rise Of Colleges..., 31-2.

${ }^{88}$ Maksum, Madrasah..., 60.

${ }^{89}$ Azra, Pendidikan..., viii.
} 
$354 \mathrm{H} / 965 \mathrm{M})$ yang menjadikan rumahnya sebagai madrasah bagi sahabat-sahabatnya atau sebagai tempat tinggal bagi orang asing yang bermukim di Naysabur, terutama mereka dari kalangan ahli hadis dan fiqh. ${ }^{90}$

Tetapi kemudian tidak dapat disangkal bahwa pengaruh madrasah Nizâmiyyah melampaui pengaruh madrasah-madrasah yang didirikan sebelumnya. Makdisi dan Syalabî misalnya menjadikan pendirian madrasah Nizâmiyyah sebagai pembatas untuk membedakan dengan orde sebelumnya. ${ }^{91}$ Orde baru itu terletak pada adanya ketentuan-ketentuan yang lebih jelas yang berkaitan dengan komponen-komponen pendidikan dan keterlibatan pemerintah dalam pengelolaan madrasah. Madrasah Nizâmiyyah merupakan lembaga pendidikan resmi dan pemerintahan terlibat dalam menetapkan tujuan-tujuannya, menggariskan kurikulum, memilih guru, dan memberikan dana yang teratur kepada madrasah. ${ }^{92}$

Dalam hal ini, Makdisi mempunyai pendapat lain, sekalipun menyetujui adanya peraturan-peraturan sebagai kelebihan madrasah, ia menganggap khususnya madrasah Nizâmiyyah sebagai madrasah perseorangan. Dalam konteks ini, Nizâm alMulk adalah seorang pribadi yang mengelola madrasah untuk tujuan sendiri (sifatnya inisiatif sendiri). ${ }^{93}$ Nizâm al-Mulk telah membangun madrasah-madrasah yang megah di berbagai tempat, seperti Baghdad, Balkh, Naysabur, Harat, Isfahan, Basrah, Marwa, Amil, dan Mawsil. ${ }^{94}$ Diduga kuat, yang menjadikan Makdisi berkesimpulan bahwa madrasah Nizâmiyyah tidak dicampuri oleh negara adalah berkaitan dengn pilihan terhadap salah satu mazhab dari mazhab Sunni yang

${ }^{90}$ Al-Dîn, Dirâsât..., 48.

${ }^{91}$ Syalabî, Tarikh..., 33 dan Makdisi. The Rise ...1981, 10-27

${ }^{92}$ Maksum. Madrasah..., 61.

${ }^{93}$ Syalabî, Târîkh...,100.

94Syalabî, Târikh..., 100; Makdisi, The Rise ...,31-2 dan Nasution, Ensiklopedi..., 742. 
berbeda dengan mazhab yang dianut oleh sultan-sultan Saljûq ketika ia menjadi wazir selama 30 tahun, baik Alp Arsalân maupun Mâlik Syah. Nizâm al-Mulk memilih mengembangkan pengajaran fiqh Syafi'î dengan kalam Asy'âriyyahnya. Sedangkan sultan-sultan Saljûq cenderung mengikuti fiqh Hanafî dengan kalam Mâturidiyyah.

Di lain sisi, khalifah 'Abbâsiyyah waktu itu dekat dengan

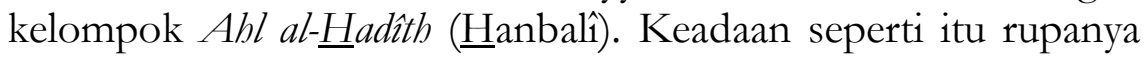
tidak akan menjadi masalah bagi Sultan Saljûq. Yang terpenting bagi mereka adalah kelanggengan kekuasaannya. Kemudian salah satu bagian dari strategi cerdas (untuk tidak mengatakan sebuah trick), kekuatan Nizâm al-Mulk dan penganut mazhabnya dimanfaatkan untuk melawan Syi'ah yang waktu itu merupakan musuh utama (the greatest enemy). ${ }^{95}$ Ketika itu, Fâtimiyyin, Saljûq, Zanki, dan Ayyubin telah mendirikan institusi/yayasan pendidikan di mana masing-masing ingin menghadapi jalan yang ditempuh oleh saingannya dan sekaligus masing-masing hendak saling mendestruksi langkah dan planning saingannya tersebut. Kemudian pendidikan dijadikan sebagai sebuah senjata untuk memerangi dan mengamputasi pengaruh yang lain, terutama melalui penanaman ideologi Syi'ah sendiri ketika itu (diwakili Fâtimiyyah dan Buwayhid) secara aktif dan sistemik kerap melakukan indoktrinisasi melalui pendidikan atau aktivitas pemikiran yang lain. ${ }^{96}$

Tidak dapat dikesampingkan, Nizâm al-Mulk tidak menyianyiakan sikap sultan-sultan Saljûq tersebut dengan memanfaatkan sarana pendidikan guna membangun sistem madrasah yang seragam dan berprestasi, serta membentuk caloncalon ulama dan birokrat yang mempunyai wawasan identik. ${ }^{97}$ Dengan demikian, untuk kasus madrasah Nizâmiyyah ini, antara sultan-sultan Saljûq dan Nizâm al-Mulk telah terjalin hubungan

\footnotetext{
${ }^{95}$ Al-Dîn, Dirâsât..., 52.

${ }^{9}$ Ibid., 52.

${ }^{97}$ Nasution, Ensiklopedi..., 742-3.
} 
simbiosis-mutualisme. Beberapa pejabat pemerintah yang sering disebut memiliki kaitan langsung dengan ide dan penyebaran madrasah adalah Nizâm al-Mulk (456-485 H), Nûr al-Dîn Zankî (9541-569 H), Salâh al-Dîn al-Ayyûbî (564-589 H), dan Mustansir bi al-Lâh (623-640 H).

Demikianlah sejarah panjang madrasah, yang pada perkembangan selanjutnya ia tetap eksis dan survive hingga kini. Namun kemudian eksistensinya menjadi dipertanyakan ketika kurikulumnya masih dimonopoli oleh al-'Ulum al-Naqliyyah Lisâniyyah (seperti tafsir, qirâ'ah, fiqh, hadis, dan ushul fiqh serta ilmu bahasa dan sastra), minus al-'Ulum al-Ajnâbiyyah-'Aqliyyah (mantiq dan tradisi berpikir filsafat). Dengan demikian menurut penilaian Azra, ilmu-ilmu non-agama atau keduniaan (profan), khususnya ilmu-ilmu kealaman dan eksakta, yang merupakan akar-akar pengembangan sains dan teknologi, sejak awal pengembangan madrasah, sudah berada pada posisi yang marginal. ${ }^{98}$ Terhadap refleksi historis-analitis guru Azra ini, membutuhkan diskursus tersendiri yang lebih patent dan independent. Lebih menarik lagi bila dijadikan kajian yang mendalam dalam bentuk tesis atau disertasi.

\section{Catatan Akhir}

Pendidikan Islam mempunyai sejarah yang panjang, dan berkembang seiring dengan perkembangan Islam itu sendiri. Kaitannya dengan ini, banyak kemudian bermunculan institusiinstitusi pendidikan yang dimulai pada masa Nabi saw. sampai masa kejayaannya pada masa Daulah'Abbâsiyyah (750-1258 M). Transformasi lembaga pendidikan dari masjid ke madrasah dianggap sebagai tonggak baru dalam penyelenggaraan pendidikan Islam. Hanya saja perlu dicatat institusi-institusi pendidikan pramadrasah tersebut tetap dipakai sesuai dengan sifat tradisionalnya, meski jumlah dan peminatnya sedikit.

${ }^{98}$ Azra, Pendidikan..., ix. 
Selanjutnya, dalam penyelenggaraan pendidikan di lembaga madrasah, keberadaan pemerintah tidak dapat diabaikan, seperti dalam menetapkan tujuannya, menggariskan kurikulum, memilih guru (termasuk mencatatnya), dan memberikan dana yang teratur. Lebih dari itu, ternyata pendirian madrasah, di samping memiliki faktor pendorong dari segi agama, budaya, dan peradaban, juga tidak terlepas dari vested interrest pemerintah yang berkuasa kal itu. Terutama karena ia dijadikan sebagai salah satu senjata pamungkas untuk mengamputasi reputasi dan pengaruh Syi'ah yang sedang berkibar. Dan pada saat yang sama, ia dijadikan sebagai mesin perekat yang sifatnya teologis untuk mengawetkan persatuan kelompok Sunnî.

\section{Daftar Pustaka}

Muhammad 'Atiyyah Abrasyî, Al-Tarbiyyah al- Islâmiyyah (t.k.: Dâr al- Qawmiyyah, 1964).

Azyumardi Azra, Pendidikan Islam: Tradisi dan Modernisasi Menuju Millenium Baru (Jakarta: LOGOS, 1999).

Hamid Hasan Bilgrami dan Sayyid Ali Ashraf. Konsep Universitas Islam ter. Machnun Husein (Yogyakarta: PT Tiara Wacana,1989).

Alhmad Syalabî, Târîkh al-Tarbiyyah al-Islâmiyyah (Kairo: Maktabah al-Englo al-Misriyyah, 1960). , Al-Tarbiyyah wa al-Ta'lìm fî̀ al-Fiker al- Islâmî (Kairo: al-Maktabah al-Nahdah al-Mishriyyah, 1987).

Cyril Glasse, Ensiklopedi Islam Ringkas, ter. Ghufran A. Mas'adi (Jakarta: Raja Grafindo Persada, 1999).

Philip K. Hitty, History of The Arabs (London: The MacMillan Press, 1974).

Abd Rahman Ibn Khaldûn, Muqaddimah Tarîkh Ibn Khaldûn (Beirut: Dâr al-Fikr, 1988).

Ibn Khallikân, Wafâyât al-A'yân wa Anbâ' Abnâ' al-Zamân I, ed. Ihsân Abbâs (Beirut: Dâr Sadr, t.t.). 
George Makdisi, The Rise of Colleges: Istitutions of Learning in Islam and The West (Edinburgh: Edinburgh University Press, 1981).

Maksum, Madrasah Sejarah dan Perkembangannya (Jakarta: LOGOS, 1999).

Muhammad Munir Mursi, Al-Tarbiyyah al-Islâmiyyah: Ushûluhâ wa Tatawnurubâ fî al-Bilâd al-Arabiyyah (Kairo: 'Alim al-Kutub, 1977).

Mehdi Nakosten, History of Islamic Origins in The Western Education (Kolorado: (Colorado University Press, 1964).

Hisham Nashabe, Muslim Educational Institutions (Beirut: Riadh Solh Square, 1980).

Harun Nasution et.el. Ensiklopedi Islam Indonesia (Jakarta: Djambatan, 1992).

Seyyed Hossein Nasr, Science and Civilization in Islam (Amerika: The New American Library, 1970).

C.A. Qadir, Philosophy and Science in The Islamic World (London: Routledge, 1990).

Fazlur Rahmân, Islâm (London: The University of Chicago Press, 1979).

Muhammad Munîr Said al-Dîn, Dirâsât fî Tarîkh al-Tarbiyyah inda al-Muslimîn (Libanon: Beirut, 1995).

J.J. Saunders, A History of Medievel Islam (London dan New York: Routledge, 1996).

Joseph S. Szyliowics, Pendidikan dan Modernisasi di Dunia Islam, ter. Murwinanti W. (Surabaya: Al-Ikhlas, 2001).

Rusman Thoyyib, Development of Muslim Educational System in the Classical Period 600-1100 A.D.: An Overview dalam Akhmad Minhaji et.al., The Dynamic of Islamic Civilization (Yogyakarta: Titian Illahi Press, 1998). 